\title{
XIMIЧНI НАУКИ
}

DOI: https://doi.org/10.32839/2304-5809/2019-10-74-77

УДК 664.41:546.33’131

Петруша Ю.Ю., Загородня Ю.С.

Запорізький національний університет

\section{ФІЗИКО-ХІМІЧНІ ПОКАЗНИКИ ЯКОСТІ ХАРЧОВОЇ ЙОДОВАНОЇ СОЛІ}

Анотація. У статті досліджено органолептичні та фрізико-хімічні показники якості харчової йодованої солі трьох торгових марок українських виробників. Проведено органолептичну оцінку якості зразків солі TM «Козаченька», «Артемсіль» та «Salute di Mare». За допомогою гравіметричного методу визначено вміст вологи та нерозчинного залишку. Встановлено, що волога харчової йодованої солі за кімнатної температури коливається від 0,20\% до 0,01\% і знаходяться в межах ДСТУ 4307:2004. Нерозчинний залишок у всіх зразках солі також відповідає вимогам ДСТУ 4307:2004 та становить від 0,003\% до 0,012\%. Якісно підтверджено наявність важких металів у всіх зразках солі різних виробників. За допомогою титриметричного методу з'ясовано, що масова частка йоду у досліджуваних зразках знаходиться біля нижньої

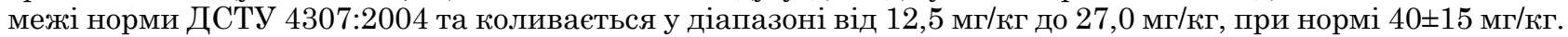
Ключові слова: харчова йодована сіль, органолептичний аналіз, вміст вологи, титриметричний аналіз, йододефіцит.

Petrusha Yuliya, Zagorodnya Yuliya Zaporizhzhya National University

\section{PHYSICO-CHEMICAL INDICATORS OF QUALITY EDIBLE IODIZED SALT}

Summary. The article investigates organoleptic and physico-chemical quality indicators of edible iodized salt of three brands of Ukrainian manufacturers. Organoleptic evaluation of the quality of salt samples "Kozachenka», "Artemsol» and «Salute di Mare» was made. With the help of the gravimetric method, the moisture content and the insoluble residue are determined. It is established that the moisture of edible iodized salt at room temperature ranges from $0.20 \%$ to $0.01 \%$ and are within DSTU 4307:2004. The insoluble residue in all salt samples also meets the requirements of DSTU 4307:2004 and ranges from 0.003\% to 0.012\%. Qualitatively confirmed the presence of heavy metals in all samples of salt from different manufacturers. Qualitative detection of heavy metal salts in salt samples was determined according to GOST 17319. In the human body, iodine is contained in small amounts $-15-20 \mathrm{mg}$. Most of the iodine (up to 90\%) a person receives with food and only a small amount with water and air. Iodine deficiency is the cause of many diseases, primarily - an increase in the thyroid gland, which causes a delay in mental and physical development of children, deafness, neurological cretinism and vision impairment. Iodized salt is used in the fight against iodine deficiency, but the product is quite unstable and after 6-12 months, iodine is almost completely evaporated and iodized salt turns into ordinary salt. Although the shelf life of iodized salt is indicated 24, 12 and 9 months, but in practice after 5-6 months of storage iodized salt loses iodine. The scanty amount of iodine remaining may not be effective in the fight against deficiency. Technologies of preparation and storage of iodized salt require strict control, since all forms of iodine are characterized by increased volatility. In this regard, iodized salt of the desired composition may not reach the consumer in the case of weak quality control during its production or loss of iodine in the finished product. The popularity of iodized salt in the food market is gaining demand. At the moment, the number of consumers of iodized salt and the average frequency of consumption of this product, as well as the number of adherents of certain brands, is growing. In this regard, the problem of quality control of iodized salt becomes urgent. Using the titrimetric method, it was found that the mass fraction of iodine in the samples borders on the lower limit of the norm of DSTU 4307:2004 and ranges from $12.5 \mathrm{mg} / \mathrm{kg}$ to $27.0 \mathrm{mg} / \mathrm{kg}$, at a norm of $40 \pm 15 \mathrm{mg} / \mathrm{kg}$.

Keywords: edible iodized salt, organoleptic analysis, moisture content, titrimetric analysis, iodine deficiency.

$\Pi$ остановка проблеми. Сіль - один із небагатьох компонентів у ращіоні людини, який незалежно від віку, місця проживання та фінансового стану вживається скрізь і практично кожним. Людина споживае сіль протягом всього року приблизно в однаковій кількості. Сіль - також один 3 небагатьох продуктів харчування, виробництво якого досить сильно пов'язане з природними копалинами [1].

Йодована сіль не відрізняється від звичайної за смаком, запахом чи кольором. Для йодування солі використовуеться не сам йод, а його хімічні сполуки. Для йодування солі діючі нормативи України дозволяють використовувати калій йодид та калій йодат (харчова добавка Е 917) [2; 3] На практиці ж вся сіль, що реалізуеться в нашій країні, збагачується переважно калій йодатом. При введенні в сіль йодованих домішок треба мати на увазі, що цей йодовмісний продукт досить нестійкий і вже за 6 місяців йодована сіль перетворюється на звичайну.

В організмі людини йод міститься в незначних кількостях - 15-20 мг. Більшу частину йоду (до 90\%) людина отримуе з продуктами харчування і лише незначну кількість - 3 водою та повітрям. Дефіцит йоду є причиною багатьох хвороб, в першу чергу - збільшення щитоподібної залози, що викликає затримку розумового та фрізичного розвитку дітей, глухонімоту, неврологічний кретинізм та погіршення зору.

Аналліз останніх досліджень i публікацій. Йододефріцитні захворювання широко роз- 
повсюджені у всьому світі (Zimmermann M.В., Andersson M.). За оцінкою ВООЗ і ЮНІСЕФ понад мільярд людей мають ризик розвитку цих захворювань, 300 млн осіб - збільшення щитоподібної залози, 30 млн страждають на кретинізм. Саме тому, пріоритетні міжнародні програми містять заходи 3 профрілактики та контролю за йододефіцитними захворюваннями поряд з програмами боротьби зі СНІДом, поліомієлітом і туберкульозом [4; 5].

Сучасні дослідження демонструють наявність йододефіциту на всій території України (Тесарівська Т.У., Маменко М.Є., Тронько М.Д.). Цю проблему можна здолати шляхом йодування кухонної солі. Такий спосіб забезпечуе організм додатковою кількістю йоду і вважається найбільш зручним, безпечним і недорогим [6].

Виділення нерозв'язаних раніш частин загальної проблеми. Технології виготовлення і зберігання йодованої солі вимагають жорсткого контролю, оскільки всі форми йоду характеризуються підвищеною леткістю. У зв'язку з цим, йодована сіль потрібного складу може так і не дійти до споживача у разі слабкого контролю якості в процесі їі виробництва або втрати йоду в готовому продукті.

Популярність йодованої солі на ринку продуктів харчування постійно збільшуеться. На теперішній момент росте кількість споживачів йодованої солі й середня частота споживання цього продукту, а також число прихильників тих чи інших марок. У зв'язку з цим, стає актуальною проблема контролю якості йодованої харчової солі.

Мета статті. Головною метою цієї роботи є порівняння органолептичних та фрізико-хімічних показників якості харчової йодованої солі різних українських виробників.

Виклад основного матеріалу. Для дослідження органолептичних властивостей та фрізикохімічних показників якості харчової йодованої солі було обрано 3 зразки різних виробників: зразок № 1 - харчова йодована сіль ТМ «Артемсіль»; зразок № 2 - морська харчова сіль йодована TM «Salute di Mare»; зразок № 3 - сіль екстра йодована ТМ «Козаченька». Найбільшим виробником солі в Україні є державне підприемство "Артемсіль", на частку якого припадає понад 90\% усієї виробленої солі в Україні. Решта підприемств виробляють відносно невелику кількість солі, і в основному, орієнтовані на поставки споживачам на місцевому ринку.

Харчова йодована сіль повинна відповідати вимогам ДСТУ 4307:2004 «Сіль йодована».

Сенсорний аналіз досліджуваних зразків проводили згідно вимог ДСТУ 4307:2004, що наведені у табл. 1 [7]. Сутність методу полягає в органолептичній оцінці смаку, запаху, кольору й зовнішнього вигляду солі.
Основними показниками контролю якості харчової йодованої солі $е$ фрізико-хімічні показники, а саме: вміст вологи, вміст нерозчинного у воді залишку, йоду, кальцію, магнію, хлору, залізистосиньородистого калію, оксиду заліза та наявність важких металів.

Вміст вологи визначали згідно ДСТУ 3583:2015. Метод засновано на висушуванні зваженої проби солі і визначенні втрати маси при висушуванні.

Масову частку йоду в йодованій солі визначали згідно ДСТУ 3583:2015. Для визначення йодистого калію застосовували перманганатний метод, який базуеться на окисненні йодидів калій перманганатом та вилученні надлишку калій перманганату щавлевою кислотою і наступному титруванні виділеного йоду натрій тіосульфатом.

Визначення масової частки нерозчинного у воді залишку проводили згідно методики ДСТУ 3583:2015 [8; 9]. Метод засновано на розчиненні заданої кількості проби солі у воді, фрільтруванні отриманого розчину, висушуванні та зважуванні нерозчинного залишку.

Якісне виявлення солей важких металів у зразках солі проводили згідно ГОСТ 17319-76 [10-12].

Статистичну обробку отриманих результатів здійснювали за допомогою t-критерію Ст'юдента i пакету комп'ютерних програм Microsoft Office Excel [13].

Результати та їх обговорення. Органолептичний аналіз $є$ одним із найважливіших методів при визначенні споживчої якості йодованої солі різних виробників. Для усіх видів регламентуються: зовнішній вигляд, смак, колір, запах, наявність домішок. На основі одержаних даних було порівняно профілі досліджуваних зразків. Результати органолептичного аналізу харчової йодованої солі наведено у табл. 2.

За даними органолептичних дослідів можна зробити висновок, що сіль ТМ «Козаченька» має найбільш якісні показники, про що свідчить відсутність присмаку та запаху йоду, як у зразку TM «Salute di Mare», та відсутність домішок, як у йодованої солі державного підприемства «Артемсіль». Органолептичні показники всіх зразків відповідають нормативному документу.

За допомогою гравіметричного аналізу визначено вміст вологи досліджуваних зразків та кількість нерозчинного залишку. Підвищена відносна вологість харчової йодованої солі сприяе їі злежуванню, яке відносять до ймовірних дефектів. Вміст нерозчинного залишку характеризує чистоту солі та наявність зайвих домішок. Згідно ДСТУ 4307 для харчової йодованої солі масова частка вологи не повинна перевищувати $1,0 \%$, а масова частка нерозчинного у воді залишку має бути не більше, ніж 0,25\%. Результати визначен-

Органолептичні показники згідно вимог ДСТУ 4307

Таблиця 1

\begin{tabular}{|l|l|l|}
\hline \multirow{2}{*}{ Назва показника } & \multicolumn{1}{|c|}{ Характеристика йодованої солі сортів } \\
\cline { 2 - 3 } & \multicolumn{1}{|c|}{ екстра і вищого } & \multicolumn{1}{|c|}{ першого } \\
\hline \multirow{2}{*}{ Зовнішній вигляд } & $\begin{array}{l}\text { Кристалічний сипкий продукт. Дозволено грудочки, які розвалюються під час легкого } \\
\text { натискування. Наявність сторонніх механічних домішок, не пов'язаних з походженням } \\
\text { солі, не дозволено }\end{array}$ \\
\hline Смак & Солоний із присмаком йодувальної добавки \\
\hline Колір & Білий & Білий з відтінками, обумовленими походженням солі \\
\hline Запах & Слабкий запах йоду, властивий продукту \\
\hline
\end{tabular}


Органолептичні показники досліджуваних зразків харчової йодованої солі

\begin{tabular}{|l|l|l|l|}
\hline \multirow{2}{*}{ Показник } & \multicolumn{1}{|c|}{ Назва харчової йодованої солі } \\
\cline { 2 - 4 } & \multicolumn{1}{|c|}{ Артемсіль } & \multicolumn{1}{c|}{ Salute di Маге } & \multicolumn{1}{c|}{ Козаченька } \\
\hline Смак & $\begin{array}{l}\text { Солоний із присмаком } \\
\text { йодувальної добавки }\end{array}$ & $\begin{array}{l}\text { Дуже солоний, } \\
\text { з присмаком йоду }\end{array}$ & Солоний, без присмаку \\
\hline Колір & $\begin{array}{l}\text { Білий, з сірим та жовтим } \\
\text { відтінком }\end{array}$ & Білий з жовтим відтінком & Білосніжний \\
\hline Запах & Присутній запах йоду & Без запаху & Без запаху \\
\hline Зовнішній вигляд & $\begin{array}{l}\text { Кристалічний сипкий продукт. З грудочками, які розсипаються під час легкого } \\
\text { натискування. }\end{array}$ \\
\hline Домішки & Темно-сірі вкраплення & Без домішок \\
\hline
\end{tabular}

Результати аналізу вмісту вологи та нерозчинного залишку

Таблиця 3 досліджуваних зразків йодованої харчової солі

\begin{tabular}{|l|c|c|c|}
\hline \multirow{2}{*}{\multicolumn{1}{|c|}{ Показник }} & \multicolumn{2}{|c|}{ Назва харчової йодованої солі } \\
\cline { 2 - 4 } & Артемсіль & Salute di Mare & Козаченька \\
\hline Масова частка вологи, \% & $0,20 \pm 0,03$ & $0,11 \pm 0,01$ & $<0,01$ \\
\hline $\begin{array}{l}\text { Масова частка нерозчинного } \\
\text { у воді залишку, \% }\end{array}$ & $0,012 \pm 0,001$ & $0,009 \pm 0,001$ & 0,003 \\
\hline
\end{tabular}

Результати аналізу вмісту йоду у досліджуваних зразках

Таблиця 4 йодованої харчової солі з плином часу

\begin{tabular}{|c|c|c|c|}
\hline $\begin{array}{l}\text { Назва харчової } \\
\text { йодованої солі }\end{array}$ & $\begin{array}{c}\text { Дата проведення } \\
\text { аналізу }\end{array}$ & $\begin{array}{c}\text { Масова частка йоду, } \\
\text { мг/кг }\end{array}$ & $\begin{array}{c}\text { Норма згідно } \\
\text { ДСТУ } 4307\end{array}$ \\
\hline \multirow{2}{*}{ Артемсіль } & 12.11 .17 & 27,0 & \multirow{2}{*}{$40 \pm 15$ мг/кг } \\
\hline & 01.04 .18 & 12,5 & \\
\hline \multirow{2}{*}{ Salute di Mare } & 12.11 .17 & 26,3 & \multirow{2}{*}{$40 \pm 15$ мг/кг } \\
\hline & 01.04 .18 & 13,8 & \\
\hline \multirow{2}{*}{ Козаченька } & 12.11 .17 & 14,5 & \multirow{2}{*}{$40 \pm 15$ мг/кг } \\
\hline & 01.04 .18 & 13,8 & \\
\hline
\end{tabular}

ня вмісту вологи та нерозчинного залишку досліджуваних зразків солі наведено в табл. 3.

Отримані результати вказують, що сіль TM «Козаченька" має найменший вміст вологи. За даними аналізу найбільш схильна до злежування і утворення моноліту сіль ДП «Артемсіль»вміст вологи в ній найбільший $(0,20 \pm 0,03 \%)$. Ceредне місце серед зразків займає йодована сіль TM «Salute di Mare» $(0,11 \pm 0,01 \%)$.

Встановлено, що сіль ТМ «Козаченька» має й найменший вміст нерозчинного залишку (0,003\%). Найбільш забрудненою домішками є сіль ДП «Артемсіль» - вміст нерозчинного залишку становить 0,012\%. Нерозчинний залишок - це невід'ємна частина харчової солі. Треба зазначити, що для того, щоб сіль відносилася до категорії харчової, нерозчинного залишку повинно бути менше, ніж 1\%. Можна зазначити, що всі зразки солі далекі від верхньої межі допустимої норми.

Відомо, що харчова йодована сіль у вигляді солей різних кислот або кислотних залишків може містити плюмбум, купрум, калій, миш'як, ртуть, цинк та кадмій. Якісний аналіз йодованої солі на наявність або відсутність солей важких металів виявив, що усі зразки містять у своєму складі важкі метали, але сіль ТМ «Козаченька» менш забруднена домішками, ніж солі від виробників ДП «Артемсіль» та TM «Salute di Mare».

Иодовану харчову сіль використовують у боротьбі з йододефіщитом, але продукт досить нестійкий і вже за 6-12 місящів йод практично випарову- ється та йодована сіль перетворюеться на звичайну харчову сіль. Наступні дослідження демонструють початковий вміст кількості йоду в зразках йодованої харчової солі та вміст йоду через пів року у цих же зразках. Масова частка йоду згідно Держстандарту повинна становити $40 \pm 15$ мг/кг. Результати дослідження наведено у табл. 4.

За результатами експерименту із трьох перевірених зразків солі тільки 2 можна назвати едективними у боротьбі 3 йододефіцитом. Дослідження показали, що вміст йоду в солі закономірно зменшуеться з плином часу зберігання. Так, після 10 місяців зберігання 3 дня виробництва (5 місяців 3 них сіль була розпакована) втрата йоду 3 йодованої солі ДП «Артемсіль» та TM «Salute di Mare» сягає 45-50\% від початкового вмісту. Найвищий початковий показник вмісту йоду - у продукції ДП «Артемсіль». Сіль цього виробника коштує найдешевше у порівнянні 3 іншими зразками. Відповідае нормам Держстандарту (з допустимими відхиленнями) i сіль TM «Salute di Mare», початковий вміст йоду в якій наближений до нижньої межі. На пакуванні солі «Козаченьки» вказано, що вміст йоду становить $15 \pm 10$ мг/кг, що заздалегідь не відповідає нормі Держстандарту (40土15,0 мг/кг). Фактичним виявився показник 14,5 мг/кг, але це єдина сіль, яка майже не втратила йод 3 плином часу. Хоча термін придатності йодованої солі вказується 24, 12 та 9 місяців, але на практиці після 5-6 місячного зберігання йодована сіль 
перестає бути едективним препаратом у боротьбі 3 йододефіцитом через значну леткість йоду. Мізерна кількість йоду, що залишається, стає неефрективною у боротьбі з дефіцитом.

\section{Висновки:}

1. Проведено органолептичний аналіз харчової йодованої солі різних виробників, за результатами якого встановлено, що сіль ТМ «Козаченька" має найкращий зовнішній вигляд, колір, смак та запах.

2. З'ясовано, що волога харчової йодованої солі за кімнатної температури коливається від 0,20\% до 0,01\% та знаходиться в межах ДСТУ 4307:2004. Отримані результати вказують, що сіль ТМ «Козаченька» має найменше значення вмісту вологи. Найбільш схильна до злежування і утворення моноліту сіль ДП «Артемсіль».

3. Встановлено, що вміст нерозчинного залишку у всіх зразках солі відповідає вимогам ДСТУ 4307:2004 та коливається від 0,003\% до 0,012\%. Сіль ТМ «Козаченька» має найменший показник вмісту нерозчинного залишку, а найбільш забрудненою є сіль ДП «Артемсіль».

4. Якісно підтверджено наявність важких металів у всіх зразках солі різних виробників.

5. Експериментально доведено, що найбільший початковий вміст йоду має сіль ДП «Артемсіль» $(67,5 \%)$, найменший - сіль ТМ «Козаченька» $(14,5 \%) .3$ плином часу вміст йоду зменшуеться і вже не відповідає нормі Держстандарту.

\section{Список літератури:}

1. Корзун В.Н., Тихоненко Ю.С., Бруслова К.М. Функціональні харчові продукти у профілактиці йоддефріцитних захворювань. Гігієна населених місиь. 2010. Вип. 55. С. 284-289.

2. Про затвердження Державної програми профілактики йодної недостатності у населення : Постанова Кабінету Міністрів України від 26.09.2002 № 1418. Офбіиійний вісник України. 2002. С. 4.

3. Про затвердження Гігієнічних вимог до дієтичних добавок : наказ Міністерства охорони здоров'я України від 19.12.2013 № 1114. Офбіиійний вісник Украӥни. 2013. С. 10.

4. Assessment of the Iodine Deficiency Disorders and monitoring their elimination. WHO, UNICEF, and ICCIDD. Geneva : WHO, Euro, NUT. 2001. P. 1-107.

5. Assessment of the Iodine Deficiency Disorders and monitoring their elimination. WHO, UNICEF, and ICCIDD. Third edition. Geneva : WHO, Euro, NUT. 2007. P. 1-98.

6. Рингач Н.О. Громадське здоров'я як чинник національної безпеки : монографія. Київ : НАДУ, 2009.296 с.

7. ДСТУ 4307: 2004. Сіль йодована. Технічні умови. [Чинний від 2004-05-28]. Вид. офіц. Київ : Держспоживстандарт України, 2005. 14 с.

8. ДСТУ 3583 : 2015. Сіль кухонна. Загальні технічні умови. [Чинний від 2015-09-28]. Вид. офіц. Київ : УкрНДНЦ, 2015. 24 с.

9. ДСТУ 3583-97. Сіль кухонна. Загальні технічні умови. [Чинний від 27.02.1998]. Вид. офіц. Київ : Держстандарт України, 1998. 15 с.

10. Смирнов В.А. Анализ лекарственных веществ. Определение общих технологических примесей : учеб. пособ. Ч. II. Самара : Самар. гос. техн. ун-т, 2008. 54 c.

11. Сульдіна T.I. Вміст важких металів в продуктах харчування і їх вплив на організм. Раціональне харчування, харчові добавки $і$ біостилулятори. 2016. № 1. С. 136-140.

12. ГОСТ 17319-76 Реактивы. Методы определения примесей тяжелых металлов (Reagents. Methods for the determination of heavy metals). [Чинний від 1977-07-01]. Москва : Изд-во стандартов, 1977. С. 96-101.

13. Барковський B.В., Барковська Н.В., Лопатін О.К. Теорія ймовірностей та математична статистика. Київ : Центр учбової літератури, 2010. 424 с.

\section{References:}

1. Korzun, V.N., Tikhonenko, Yu.S., \& Bruslova, K.M. (2010). Funktsionalni kharchovi producty u profilaktytsi yoddefitsitnyh zakhvoryuvan [Functional foods in the prevention of iodine deficiency]. Gigiena naselenykh mists, no. 55, pp. 284-289.

2. Pro zatverdzhennya Derzhavnoy programy profilaktyky yodnoy nedostatnosti u naselennya [On approval of the State program for prevention of iodine deficiency in the population]. Ofitsiyniy visnyk Ukrainy, 2002, p. 4.

3. Pro zatverdzhennya Gigienichnukh vymog do dietychnykh dobavok [On approval of hygienic requirements for dietary supplements]. Ofitsiyniy visnyk Ukrainy, 2013, p. 10.

4. Assessment of the Iodine Deficiency Disorders and monitoring their elimination. WHO, UNICEF, and ICCIDD. Geneva : WHO, Euro, NUT. 2001, pp. 1-107.

5. Assessment of the Iodine Deficiency Disorders and monitoring their elimination. WHO, UNICEF, and ICCIDD. Third edition. Geneva : WHO, Euro, NUT. 2007, pp. 1-98.

6. Ringach N.O. (2009) Gromads `ke zdoroviya yak chynnyk natsionalnoy bezpeky [Public health as a factor of national security]. Kyiv, 296 p.

7. DSTU 4307:2004. Sil yodovana. Tekhnichni umovy [Iodised salt. Specifications]. Kyiv : Derzhspozhyvstandart Ukrainy, 2005, $14 \mathrm{p}$.

8. DSTU 3583:2015. Sil kukhonna. Zagalni tekhnichni umovy [Table salt. General specifications]. Kyiv : UkrNDNTS, $2015,24 \mathrm{p}$.

9. DSTU 3583-97. Sil kukhonna. Zagalni tekhnichni umovy [Table salt. General specifications]. Kyiv : Derzhstandart Ukrainy, 1998, $15 \mathrm{p}$.

10. Smirnov, V.A. (2008). Analiz lekarstvennykh veschestv. Opredelenie obschikh tekhnologicheskikh primesei [Analysis of medicinal substances. Determination of common process impurities]. Samara, $54 \mathrm{p}$.

11. Sul'dina, T.I. (2016). Vmist vazhkykh metaliv v produktakh kharchuvannya i ikh vplyv na organizm [The content of heavy metals in food and their effect on the body]. Ratsionalne kharchuvannya, kharchovi dobavky i biostymulyatory, no 1, pp. 136-140.

12. GOST 17319-76 Reaktivy. Metody opredeleniya primesey tyazhelykh metallov [Reagents. Methods for the determination of heavy metals]. Moskva : Izdatelstvo standartov, 1977, pp. 96-101.

13. Barkovskiy, V.V., Barkovska, N.V., \& Lopatin, O.K. (2010). Teoriya ymovirnostey ta matematychna statystyka [Probability theory and mathematical statistics]. Kyiv, $424 \mathrm{p}$. 